\title{
ENTRANCE LEVEL BUSINESS STRATEGIES IN EXPORT FOR BEGINNER EXPORTERS: A FIELD STUDY IN TURKEY
}

DOI: 10.17261/Pressacademia.2021.1427

PAP- V.13-2021(16)-p.84-90

\section{Duygu Hidiroglu}

Mersin University, Faculty of Tourism, Mersin, Turkey.

duyguhdr@mersin.edu.tr, ORCID: 0000-0003-2647-8750

To cite this document

Hidiroglu, D., (2021). Entrance level business strategies in export for beginner exporters: a field study in Turkey. PressAcademia Procedia (PAP), V.13, 84-90.

Permanent link to this document: $\underline{\text { http://doi.org/10.17261/Pressacademia.2021.1427 }}$

Copyright: Published by PressAcademia and limited licensed re-use rights only.

\begin{abstract}
Purpose- This study aims to guide companies that decide to start and improve their exports in current period. In the study, how exporting companies, especially SMEs, decide on the markets they should focus on in the new period, and which institutions and organizations can obtain the most accurate information to exporters while doing market research are discussed.

Methodology- The world economy is experiencing more and more global trade wars. This chaotic situation is both an opportunity and a risk for Turkey. The trade wars, which broke out as giant economies such as the USA, China and the EU raised their customs walls, have now greatly affected many countries, including Turkey. Therefore, exports have become more important than ever for Turkish companies, like many international companies that have a desire to take a place in global trade and try to overcome the stagnation that is slowly emerging in the domestic market. In this study, how to reach accurate information about potential customers and existing customers and what specifications should exporters pay attention while begining exportation are mentioned. Further, the study is concluded by giving vital clues about which business strategies and action plans should be applied to become successful in the early stage of exportation facilities Findings- The beginner exporters in Turkey should prepare a separate export plan for each country and each market. In today's business world, marketing and sales are generally accepted as the same concept but that is actually wrong. Sales is not totally marketing but is a part of marketing. Therefore, the export plan should include more than advertising and selling strategies (Roy and Banerjee, 2012: 161-163). A successful export plan should include stages such as market research, product development, foreing trade and customs regulations, export strategy, pricing, payment, shipping methods, logistics and distribution, financing, after-sales strategy, export forecasts and implementation plan. One of the biggest factors in the development of e-commerce in Turkey is the development of logistics infrastructure. This development has encouraged to produce logistics solutions different from classical retail in order to meet the variable demands of consumers and to provide short delivery to different points worldwide. Turkey; has a very important position in terms of both its regional location and product variety. Considering Turkey's dynamic characteristics, production and infrastructure, it is inevitable that cross-border online sales figures are not yet at the desired level, but with the support of SMEs and individual entrepreneurs, it will become an e-export base in a short time.

Conclusion- In summary, before an exporters first enter a new market, the exporter should determine what has happened in that market before and what should be defined as a business target for the future. Besides the exporter should also decide what is required to achieve this business target and should determine the right methods to achieve business goals. Besides, having realistic and actionable goals is important. Every member of the company should be aware of business goals and support strategic business plans. The exporter should check the exportation progress towards business goals and stick to strategic plans as much as possible.
\end{abstract}

Keywords: Turkish export, business strategies, beginner exporters, entrance level export.

JEL Codes: M10, L10, F10

\section{INTRODUCTION}

In a company that has just started foreign trade, first of all, a person suitable for the position should be recruited with the competence to undertake the export business. The company aiming to be successful in export should plan its market segmentation in detail. The company should focus on selling a lot by keeping the price low by aiming to earn from the release of the product it will launch, or it should focus on selling a small number of products at a high price with a high profit margin. Before deciding on one of these two different market strategies, the company must first determine the most profitable part of the market for its product, namely its segment. 
The positioning strategy should be in line with the pricing strategy. Before deciding on the company's positioning strategy, it should first understand the wishes and needs of the target audience, that is, the individuals who will buy its own product. The company that understands these needs correctly should then produce the product that will meet the demands and needs of the end users that the company targets.

Benefiting from training and consultancy support of the company during product development phases, market research and anticipating customer expectations and demands allows the company to reach more realistic findings by making less mistakes in the future predictions. For example, if the firm knows the support and incentives provided by the government in its sector and demands non-refundable aid from the government; will be able to easily achieve superior success at these stages. In addition to the various opportunities offered by the state, the assistance that can be obtained from accredited educational institutions and many experienced consultancy firms will also cause the company to make fewer mistakes in its first export experiences.

\section{LITERATURE THE INTRODUCTION LETTER OF COMPANY}

One of the first important steps that the company will take when stepping into export is to prepare a promotional letter for the company and its products. This is one of the most important jobs for the company and it has to be done first.

There are many useful web sites that direct new started companies. The first one is "http://www.igeme.gov.tr- GTiP Kod Rehberi". Companies that will start exporting in Turkey can obtain detailed information about the HS Code of the products from these websites mentioned above. In addition to this, companies can get support from IGEME or Exporters' Association experts by consulting Customs Brokers by accessing expert information on the subject (Ding et. Al., 2015: 1465-1467).

Export Development Center (IGEME); conducts research and development studies to form new markets and job opportunities in the field of foreign trade. It helps the exporters to increase their share in foreign markets (Zainuddin et. Al., 2019: 59). IGEME provides commercial information to domestic and foreign business circles by conducting training, broadcasting and promotional activities and contributes to the diversification of the exports in terms of products and markets, and to the development of them qualitatively and quantitatively (IGEME, 2021).

Furthermore IGEME; in line with these activities, provides the required support to exporters and companies having export potential in near future so that the companies and exporters can export and increase their export capacity (Ouyang, 2016:92). In this sense, various training activities in order to develop exportation are carried out, fairs are planned, participation in fairs is ensured, and activities are supported with various publications by IGEME.

IGEME also has useful company database inclusive with the earnings data of exporters in Turkey. The export data have increased year by year. Besides, IGEME provides guidance to exporters in early stages of theri exportation facilities by offering and informing them business opportunities. If the HS Code of the product to be exported is known, it is much easier to access international statistics and various information (Berger and Nitsch, 2008:3). In order to enable exporting companies to access HS Codes of the product with a user-friendly approach, an "electronic-dictionary" feature has been added to the HS Code scale. Query can be made separately for HS Code of the product, English or Turkish product names, and they can reach the HS Code of the product by giving the Turkish or English name of the product with the help of a dictionary (Ege and Ege, 2017:38-42). The glossary can be accessed from the Reference Resources heading or the Commercial Information Request heading.

The other useful website fort he beginner exporters is http://www.gumrukler.gov.tr" in Turkey.

Due to the establishment of the Customs Union between Turkey and the Eropean Union (EU), the "Customs Law" was published in 1999 in order to reflect the provisions in the Community Customs Code to the Customs Law in accordance with the Decision of the Association Council, and with the "Law of Fight Against Smuggling" published in 2007, all customs crimes new regulations were made (https://ticaret.gov.tr/kurumsal/tarihce).

Continuing its activities as the Undersecretariat of Customs for 18 years until 2011, the institution, with the "Decree Law on the Organization and Duties of the Ministry of Customs and Trade", By merging its four General Directorates, the customs organization was restructured at the ministerial level as the Ministry of Customs and Trade. Since 2011, the two institutions that have been operating as the Ministry of Economy and the Ministry of Customs and Trade were merged.

The main mission of the Ministry of Customs and Trade is to contribute to sustainable economic growth and social welfare; to realize, implement and coordinate with an innovative and participatory approach by planning effective, quick and people-oriented trade and customs policies. These customs policies could support companies and exporters to gain competitive advantages among their rivals (Aho, 2015: 3768). By international economic and commercial cooperation, customs policies could protect Turkish producers and consumers and also support Turkish exporters and entrepreneurs. The vision of the Ministry of Customs and Trade in Turkey is to lead sustainable economic growth by promoting high-technology and high-value-added exports by making especially foreing trade more competitive and secure.

\section{TARGET MARKET DETERMINATION}

At this stage by searching at the world import-export statistics, the new companies can easily identify the countries that have purchasing power and that are constantly buying. Companies; at this stage, can benefit from websites such as "http://www.trademap.org" and "http://comtrade.un.org" or can get support from IGEME experts. 
By assuming a company in one sector, while defining the countries for market entry study for the company, the decision makers in that company should define and consider objective criteria for country selection although the selection is commonly a personal decision.

\subsection{Distribution Channels in the Target Market for Potential Customers}

While defining the distribution channels in the target market; in other words, while predicting potential customers, the company must determine whom can buy its products. The distribution channels for the products could be (He et. Al., 2013:31-33);

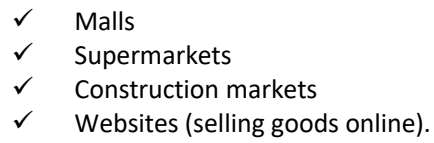

The company should benefit from the market reports while deciding best distribution channels for its products. These market reports are avaliable at IGEME (Country-Sector-On-Site Market Research) and Exporters' Associations such as Turkish Exporters' Assembly (TIM) and Foreign Economic Relations Board (DEIK). The company also could get help of Turkish Commercial Counselors in many countries.

IGEME is Export Development Center and it conducts research and development studies to form new markets and business opportunities in the field of international trade as mentioned above.

On the other hand, the foremost association among all exporters' associations in Turkey is called Turkish Exporters Assembly (TIM). Turkish Exporters Assembly (TIM); with the instructions of Atatürk who is the founder of Turkey, has its roots in order to direct Turkey's foreign trade, plan the export policies, develop market diversity and facilitate the rivalry of exporters in the global market. It is the roof of all organizations of Turkish Exporters' Associations based on the Livestock Exporters' Association Turkish Joint Stock Company, which was established on the year 1937 (Exporters'Assembly Turkish, 2016: 16-43).

TIM is the roof association of all Turkish exports, representing almost 30 sectors, more than 60 Exporters' Associations and more than 95 thousand exporters. Turkish Exporters Assembly, which was formed in 1993 by the permission of the Council of Ministers, sustains its facilities according to limitations of Turkish Law. The primary mission of the Assembly is; in order to reach the target of Turkey, which has a foreign trade surplus, to increase the sustainable foreign trade volume, to develop bilateral commercial and cultural relations with the other countries, bring the private and the public sector together to reach export goals (Exporters'Assembly Turkish, 2016: 43-65).

In order to sustain existing relation between the government and the exporters, TIM supports activities targeted at removing all problems and negativities in industry and export. Turkish Exporters' Assembly, which decides strategic plans for the improvement of the macroeconomy and exports with the Government, leads crucial facilities such as export strategies, innovative strategies, incubation centers and promoting strategies of Turkey and Turkish Trade Centers (Exporters'Assembly Turkish, 2016: 8-21).

TIM, which is more and more efficient with the mass it serves through the exporters' associations operating under it, also coordinates the relations with the foreign trade communities of the countries it cooperates with. In this context, our Assembly, which is a member of the International Trade Center (ITC), represents Turkey before the ITC and improves its connections with other foreign trade support organizations that are members of the ITC (Exporters'Assembly Turkish, 2016: 87-89).

TIM organizes lots of organizations and many trade delegations in order to support the commercial activities of Turkish exporters abroad. TIM has a vital role in the improvement of relations by signing goodwill agreements with foreign trade partner countries. In addition, it conducts research activities related to the reputation of Turkish export goods abroad and conducts field research on perception studies and awareness, trustworthiness and preference of Turkish goods.

Established in 1985, the Foreign Economic Relations Board (DEIK) manages the foreign economic relations of the private sector in Turkey, particularly foreign trade, international investments, services, contracting and logistics; researching investment opportunities at hometown and abroad. DEIK is the institution tasked with contributing to increase Turkey's exports and coordinating similar business development activities (Atli, 2011: 109-124). DEIK is a voluntary 'business diplomacy' organization formed by Turkey's leading entrepreneurs and business world representatives, together with its Founding Organizations, members and Business Councils.

DEIK aims to develop cooperation between Turkey and other foreign countries in terms of a variety of sectors and to increase the bilateral trade volume by organizing events of an international trading facilities. Bringing together high-level representatives from Turkey and other countries, politicians, business world representatives, business people, entrepreneurs, academics and representatives of non-governmental organizations, DEIK carries out studies on supporting quality business and encouraging cooperation. DEIK strives to establish cooperation with international organizations and to discover and evaluate new opportunities for the Turkish business world through cooperation and exportation (Alici and Ucal, 2003: 11-13).

DEIK, which has purposes on carrying out exportation focused on "competence" as well as on "activity", carries out strategy development studies on issues within the scope of foreign economic relations. DEIK sheds light on the foreign economic relations of the Turkish business world with the reports, publications and facilities it plans. In this framework, DEik constantly renews its institutional initiatives to develop competence capacities such as service exports, mutual investments, and increasing export and financing capacities of SMEs, which are within the scope of foreign economic relations, in line with the changing conditions of the era. It is realized through "Working Groups" formed among DEIK members (Tür, 2011: 399). 
The primary duty of a Commercial Counselor or Attaché; to make every effort to increase the export of Turkish goods to the country for which it is responsible. However, in addition to this basic and comprehensive task of the commercial consultant, there are also duties that the majority of them are not aware of. These tasks could be (Colakoglu, 2015: 9-17);

\begin{abstract}
Taking samples from the warehouse of the importer company for a disputed party; Attempting to reconcile the parties to resolve a commercial dispute;

Participating in the negotiations with the buyers together with our exporting companies if there is a demand;

Being involved in the appraisal processes regarding the planned, that is, intentional "destruction" attempts of the buyers, especially the fresh fruit and vegetables exported on consignment;

Solving or trying to solve the problem in the event that trucks carrying our export products are detained for reasons such as lack of documents at the borders of the receiving country;

Entering arbitration proceedings as an observer by establishing good relations with the chambers of commerce in that country;

In cases where the buyer is suspicious, conducting intelligence research and to be active in the event on many other similar issues.
\end{abstract}

\title{
3.2. Advertising and Promotion Methods for Existing Customers
}

In terms of advertising and promotion methods for customers, firms should learn the most useful promotion methods that will bring results in the target country as soon as possible and at the lowest cost. The low priced advertising and promotion methods for customers could be (Hultman et. Al., 2011: 21- 34);

\author{
Fairs \\ Magazines \\ Websites \\ Brochure for advertising and sales magazine.
}

While defining advertising and promotion methods for customers firms could benefit from tha data from a variety of related databases in Turkey:

\author{
IGEME (Country-Sector-On-Site Market Research- On-line Databases) \\ Exporters' Associations \\ DEIK \\ Trade Consultants (https://ticaret.gov.tr/yurtdisi-teskilati) \\ www.cbi.eu for EU
}

$\mathrm{CBI}$ is the Center for Promotion of Imports in developing countries. The main purpose of $\mathrm{CBI}$ is to support the transition to inclusive and sustainable economies by strengthening the sustainability of SMEs in developing countries. CBI is to facilitate and encourage SMEs to export their value added products to Europe from their home countries (Kester, 2011: 32).

\section{ENTRANCE LEVEL BUSINESS STRATEGIES IN TURKISH EXPORT FOR BEGINNER EXPORTERS}

Identifying Potential Customers - After completing the above-mentioned stages one by one, end users who have positive feedback on Company's offer should be contacted. End users should either be called individually or, if necessary, on-site customer visits should be made to complete the Market Research, using government support.

Requesting Information and Recipient Address from Commercial Counselors - Firms should request the detailed information and recipient addresses from the commercial counselors to gather potential customers' information appropriately (Gençtürk and Kotabe, 2001:69-72). The recipient address should be obtained from http://www.musavirlik.gov.tr by Turkish exporters. The recipient address request can be sent to the commerical counselors via this website with a company introduction letter.

Requesting Importers' Addresses from Export Development Center (IGEME) - Firms could either request importers' addresses and detailed information from IGEME or they could search this information in the library.

Searching for Purchase Requests and Potential Customers from B2B E-Markets - B2B e-commerce and e-marketplaces have gained importance recently. Business to business (B2B) represents a 'firm to company' sales strategy. The main purpose of companies operating as B2B is to improve each other's services. When it comes to B2B, every company applies the B2B business model in order to continue its production activities (Alrubaiee et. al., 2012: 22-26). The main working areas of the B2B business model are as follows (Pyper et. al., 2019: 99-118):

In the B2B business model in Raw Material Trade, a firm supplies the raw materials it will need throughout the production process through another firm.

In B2B Business Model in Wholesale Trade; A firm can sell its products to another firm that sells wholesale.

If there is a B2B business model in Operational Collaborations; A company can get support from other companies for the services it needs. These supports are generally available in areas where the company is insufficient. For example, if there are issues related to public relations that the company is insufficient; The firm can get support from a consultancy firm specialized in this field. The same applies to the consultancy service received from the advertising agency to develop the marketing and promotion strategies of the products. 
A car brand manufacturer is given as an example of an oprational colloborations of B2B business model. In order for a car to get there, many parts (from the electrical components to the tire) must be brought together. Before starting the production process, these parts are supplied and then a car is produced. When the car company brings these parts together by supplying them from different suppliers and when they sell a car, they actually sell a joint work of dozens of brands not just one brand (Roy and Banerjee, 2012: 142-154).

\section{Searching for Purchase Requests and Potential Customers from B2C Business Model, E-commerce and Marketing}

Business to consumer (B2C) refers to 'company to consumer' business model which describes the direct commercial relations between companies and consumers. All shopping facilities peopl do individually in their daily life could be explained as a $\mathrm{B} 2 \mathrm{C}$ business model. Concerning today's high level technology, the B2C business model is examined in two different ways. Based on one B2C model, manufacturers sell directly to consumers through their own virtual stores. In this B2C business model, the manufacturers offer their products to consumers at ex-factory prices (Miao ET. AL., 2019: 851-853)

Another B2C business model includes virtual marketplaces. This B2C business model is emerged with the development of e-commerce. This model presents the products purchased from the suppliers to the consumer by adding profit on basic prices. E-commerce sites are the most preferred shopping addresss catering the recent shopping expectations. The virtual POS systems and a wider product ranges are only a couple of advantages of the e-commerce sites (Täuscher and Laudien, 2018: 321-328).

With the development of the e-commerce sector in Turkey, the B2C business model stands out more. With this method, even a small business or a strat-up business can sell to any place where the internet is available. E-commerce sites, which can invest in their business by getting rid of the physical costs or inventory costs of traditional sales methods, are developing day by day.

On the other hand, B2C business model and e-commerce have taken the biggest step in secure shopping with virtual POS. The virtual POS offer next-day pay-as-you-go virtual POS service, weepay named product weePos. Receiving and making reliable payments means the basics of e-commerce. weepay, which is approved by the Banking Regulation and Supervision Agency and uses a special fraud system in payments, provides convenience for both the customer and the store owner at this point. The SSL certificate and 3D Secure security system on the payment page instill trust and ensure that e-commerce is carried out smoothly (Wang et. al., 2018: 4362).

\section{DISCUSSION}

Although B2B and B2C business models have stages of advertising, promotion, product promotion and meeting with the end consumer, there are distinct differences between these two business models. These differences reveal the marketing techniques used. For instance, the business partnership of B2B is not with the consumer but the other company. Since the B2C model caters to the needs of consumers, the probability of a product being sold to the same person is very low (lankova et. al., 2019: 171-172) However, since the B2B business model is contracted with a company, it is highly likely that the company will cooperate with you if the company is satisfied with the product during the production process.

In the B2B business model, products are sold logically according to their quality and utility. In other words, product marketing with the B2B model is easier to persuade the other party. But shopping in the B2C business model is emotional, even if it is necessary. It is more difficult to address people.

In the $\mathrm{B} 2 \mathrm{C}$ business model, you must meet the commitments you make to the consumer during the sale. Product price, delivery terms are non-negotiable. In B2B, on the other hand, you can discuss the price and shipping conditions even after the sale and make a mutual decision (lankova et. al., 2019: 174-179).

\section{- $\quad$ IGEME TBRH (Commercial Information Resources Guidance Services)}

On the purpose of searching purchase demands and the detailed information about potential customer addresses from B2B and emarketplaces companies that will start exporting could take advantage of following websites (Savrul et. al., 2014: 38-39):

$$
\begin{aligned}
& \text { www.emarketservices.com, } \\
& \text { www.intracen.org/countries. }
\end{aligned}
$$

Moreover, new exporters or companies could select a country from "www.worldchambers.com" and request the particular information from Turkish Chamber of Commerce and Industry.

\section{CONCLUSION}

In summary, before an exporters first enter a new market, the exporter should determine what has happened in that market before and what should be defined as a business target for the future. Besides the exporter should also decide what is required to achieve this business target and should determine the right methods to achieve business goals. Besides, having realistic and actionable goals is important. Every member of the company should be aware of business goals and support strategic business plans. The exporter should check the exportation progress towards business goals and stick to strategic plans as much as possible.

The beginner exporters in Turkey should prepare a separate export plan for each country and each market. In today's business world, marketing and sales are generally accepted as the same concept but that is actually wrong. Sales is not totally marketing but is a part of marketing. Therefore, the export plan should include more than advertising and selling strategies (Roy and Banerjee, 2012: 161-163). A successful export plan should include stages such as market research, product development, foreing trade and customs regulations, export 
strategy, pricing, payment, shipping methods, logistics and distribution, financing, after-sales strategy, export forecasts and implementation plan.

One of the biggest factors in the development of e-commerce in Turkey is the development of logistics infrastructure. This development has encouraged to produce logistics solutions different from classical retail in order to meet the variable demands of consumers and to provide short delivery to different points worldwide. Turkey; has a very important position in terms of both its regional location and product variety. Considering Turkey's dynamic characteristics, production and infrastructure, it is inevitable that cross-border online sales figures are not yet at the desired level, but with the support of SMEs and individual entrepreneurs, it will become an e-export base in a short time.

\section{REFERENCES}

Aho, M. (2015). A tool for organizations to quickly assess growth potential in foreign markets: Internationalization and the HS code.1-73.

Alıcı, A. A., \& Ucal, M. Ş. (2003). Foreign direct investment, exports and output growth of Turkey: Causality analysis. In European Trade Study Group (ETSG) fifth annual conference, Madrid. 11-13.

Alrubaiee, L., Alshaibi, H., \& Al-bayati, Y. (2012). Relationship between B2B e-commerce benefits, e-marketplace usage and supply chain management. Global Journal of Management and Business Research, 12(9), 22-26.

Atli, A. (2011). Businessmen as Diplomats: The Role of Business Associations in Turkey's Foreign Economic Policy. Insight Turkey, 13(1), 109128.

Berger, H., \& Nitsch, V. (2008). Gotcha! A profile of smuggling in international trade. Berger, Helge and Nitsch, Volker, Gotcha! A Profile of Smuggling in International Trade (November 2008). CESifo Working Paper Series No. 2475, Available at SSRN: https://ssrn.com/abstract=1310068.1-32.

Colakoglu, S. (2015). Dynamics of Sino-Turkish Relations: A Turkish Perspective. East Asia, 32(1), 7-23.

Ding, L., Fan, Z., \& Chen, D. (2015). Auto-categorization of HS code using background net approach. Procedia Computer Science, 60, 14621471.

Ege, A., \& Ege, A. Y. (2017). The Turkish economy and the challenge of technology: a trade perspective. New Perspectives on Turkey, 57, 3160 .

Exporters'Assembly Turkish. (2016). Economy and Foreign Trade Report. 1-146.

Gençtürk, E. F., \& Kotabe, M. (2001). The effect of export assistance program usage on export performance: a contingency explanation. Journal of international marketing, 9(2), 51-72.

He, X., Brouthers, K. D., \& Filatotchev, I. (2013). Resource-based and institutional perspectives on export channel selection and export performance. Journal of Management, 39(1), 27-47.

Hultman, M., Katsikeas, C. S., \& Robson, M. J. (2011). Export promotion strategy and performance: the role of international experience. Journal of international marketing, 19(4), 17-39.

lankova, S., Davies, I., Archer-Brown, C., Marder, B., \& Yau, A. (2019). A comparison of social media marketing between B2B, B2C and mixed business models. Industrial Marketing Management, 81, 169-179.

IGEME. (2021). https://igeme.com.tr/hakkimizda/

Kester, T. J. (2011). Coaching for export success. In International Trade Forum, International Trade Centre. 2 (1), 32.

Miao, Y., Du, R., Li, J., \& Westland, J. C. (2019). A two-sided matching model in the context of B2B export cross-border e-commerce. Electronic Commerce Research, 19(4), 841-861.

Ouyang, J. (2016). Import Competition and Export Dual Margins of Multi-Product Firms. Open Journal of Social Sciences, 4(04), 92.

Pyper, K., Doherty, A. M., Gounaris, S., \& Wilson, A. (2019). Investigating international strategic brand management and export performance outcomes in the B2B context. International Marketing Review.37(1), 98-129.

Roy, D., \& Banerjee, S. (2012). Strategic branding roadmap for SMEs operating in business-to-business sector: A study on Indian auto component sector. Journal of Research in Marketing and Entrepreneurship.14 (2), 142-163.

Savrul, M., Incekara, A., \& Sener, S. (2014). The potential of e-commerce for SMEs in a globalizing business environment. Procedia-Social and Behavioral Sciences, 150, 35-45.

Täuscher, K., \& Laudien, S. M. (2018). Understanding platform business models: A mixed methods study of marketplaces. European Management Journal, 36(3), 319-329.

Tür, Ö. (2011). Economic relations with the middle east under the AKP-trade, business community and reintegration with neighboring zones. Turkish Studies, 12(4), 589-602. 
Wang, Y., Jia, F., Schoenherr, T., \& Gong, Y. (2018). Supply chain-based business model innovation: the case of a cross-border E-commerce company. Sustainability, 10(12), 4362.

Zainuddin, Z., Sinaga, B. M., Hartoyo, S., \& Erwidodo, E. (2019). Assessing Market Power, Impact of Import Tariff Reductions and Weakening Demand for Rubber Products (HS code 4011) in the Australian Market. International Journal of Economics and Financial Issues, 9 (2), 59. 